\title{
The comparative yield of large-herb plants when growing in the Middle Urals
}

\author{
V. V. Valdayskikh ${ }^{1 \bowtie}$, E. P. Artemyeva ${ }^{1,2}$, M. Yu. Karpukhin ${ }^{3}$, R. V. Mikhalishchev ${ }^{1}$ \\ ${ }^{1}$ Ural Federal University named after the first President of Russia B. N. Yeltsin, Ekaterinburg, Russia \\ ${ }^{2}$ Ural State University of Railway Transport, Ekaterinburg, Russia \\ ${ }^{3}$ Ural State Agrarian University, Ekaterinburg, Russia \\ ${ }^{\square}$ E-mail:v_vald@mail.ru
}

Abstract. The purpose of the research is to isolate species of annual and perennial herbaceous plants that are promising for the tasks of accelerating the sequestration of atmospheric carbon, resistant to local soil and climatic conditions and having high productivity from the collection fund of the botanical garden of the Ural Federal University. Methods. The article presents data on the productivity of four types of herbaceous plants: Amaranthus caudatus L., Amaranthus cruentus L., Polygonum weyrichii F. Schmidt и Echinops sphaerocephalus L., grown in the botanical garden. All the research objects were grown under the same conditions. Productivity was measured at the beginning of September. The data were processed using standard statistical methods. Results. It was revealed that the plants $P$. weyrichii is the most productive in terms of both fresh and dry yield. The yield of the $P$. weyrichii increases in years with sufficiently high moisture content. Aridity and high summer temperatures have a negative impact on the growth of the $P$. weyrichii. Amaranths gain a large aboveground mass due to their belonging to the group with the $\mathrm{C}_{4}$ type of photosynthesis. High summer temperatures have a positive effect on the growth and development of amaranths, while correlations with the amount of precipitation are statistically insignificant. The plants $E$. sphaerocephalus showed average values for productivity and requires further study. It is recommended to grow the plants P. weyrichii in a sufficiently humid area. Amaranth, being a drought-resistant plant, is highly productive in any years, especially in years with the value of the hydrothermal coefficient (HTC) less than 1.0. The scientific novelty $>$ lies in the fact that the features of the cultivation of the studied crops are considered not only for forage purposes but also from the point of view of atmospheric carbon deposition and cultivation on potential carbon farms in the changing climate of the region.

Keywords: amaranth, Polygonum weyrichii, Echinops sphaerocephalus, large-herb plants, productivity, carbon farms.

For citation: Valdayskikh V. V., Artemyeva E. P., Karpukhin M. Yu., Mikhalishchev R. V. Comparative yield of large-herb plants when grown in the Middle Urals // Agrarian Bulletin of the Urals. 2021. No. 11 (214). Pp. 2-7. DOI: 10.32417/1997-4868-2021-214-11-2-7.

Date of paper submission: 04.10.2021, date of review: 08.10.2021, date of acceptance: 13.10.2021.

\section{Introduction}

Within the framework of the currently topical carbon theme, associated with the need to reduce the growth rate of the concentration of greenhouse gases in the surface layer of the atmosphere, an increase in interest in largeherb plants has been noted. This is due to their high rate of biomass accumulation and, as a consequence, to the relatively high rate of sequestration of carbon dioxide by these plants. It is obvious that one of the main roles in carbon sequestration is played by woody communities with a long-term pool of carbon in wood, but the sequestration capacity of large-herbaceous crops is expected to be comparable to that of woody plants, provided that the problems of further use of aboveground biomass are solved. Large herb plants are essential for sustainable communities and should be considered the focus of attention when establishing carbon farms.
In the botanical garden of the Ural Federal University named after the first President of Russia B. N. Yeltsin (UrFU), a collection of large-herb perennial plants has been formed over the past forty years, numbering 15 species from various families, most of which are foreign-regional species, with which a complex of perennial introduction measures for their introduction into a culture in the Middle Ural conditions [1]. These herbaceous plants are characterized by high aboveground biomass and productive longevity. Large-herb plants are of multifunctional importance and can be used for various purposes: food, feed, technical, medicinal, for the remediation of industrially contaminated areas, biofuel production, etc.

The purpose of our research was to study the productivity indicators of annual and perennial herbaceous plants of different species in the Middle Ural conditions. 
The tasks included:

1) measurement of wet and dry above-ground mass in two species of annuals and two species of perennial plants;

2) comparison of productivity indicators of the studied species with data known in the literature;

3) identification of promising species for further detailed study.

\section{Methods}

The work was carried out in the Botanical Garden of UrFU, located at $56^{\circ} 50^{\prime}$ north latitude and $60^{\circ} 36^{\prime}$ east longitude, $255 \mathrm{~m}$ above sea level. The plants were grown under automorphic conditions on well-drained, cultivated soddy-weakly podzolic medium loamy soils formed on granite eluvium-diluvium. The soils are characterized by a relatively high humus content in the arable horizon (5.8-7.9\%), close to the neutral reaction of the medium ( $\mathrm{pH} \mathrm{KCl}$ from 6.0 to 6.5 with a decrease to $4.3-4.7$ in the illuvial horizons), a fairly high supply of potassium forms available to plants (10.43-16.15 mg / $100 \mathrm{~g}$ of soil) and phosphorus (19.83-21.19 mg / $100 \mathrm{~g}$ of soil) in the arable horizon.

Climatic conditions of the studied territory are moderate continental. According to long-term average observations carried out in the botanical garden, the period of active vegetation with temperatures above $10^{\circ} \mathrm{C}$ lasts about 130 days, with temperatures above $15{ }^{\circ} \mathrm{C}$ (meteorological summer) on average 77 days. To assess the weather conditions of the growing season, the hydrothermal coefficient (HTC) was calculated according to the formula of G. T. Selyaninov: HTC $=\Sigma r \cdot 10 / \Sigma t$, where $\Sigma r$ is the sum of precipitation for the period with temperatures above $10{ }^{\circ} \mathrm{C}(\mathrm{mm}), \Sigma t$ is the sum of the average daily active temperatures (above $10{ }^{\circ} \mathrm{C}$ ) during the growing season $\left({ }^{\circ} \mathrm{C}\right)$. This criterion, characterizing the ratio of moisture and heat, has its optimal value for each cultivated species.

The objects of the study were two annual amaranth species Amaranthus caudatus L. and A. cruentus L. from the Amaranthaceae family, as well as two perennial species: Polygonum weyrichii F. Schmidt (family Polygonaceae) and Echinops sphaerocephalus L. (family Compositae) [2].

Amaranth seeds were sown in the third decade of May 2021 in order to avoid damage to seedlings by recurrent frosts in the first decade of June. The distance between the rows in the collection nursery was $0.5-$ $0.6 \mathrm{~m}$. After the emergence of seedlings thinning and weeding were carried out if necessary. Perennial $P$. weyrichii and E. sphaerocephalus have constantly grown in experimental plots for more than twenty years thanks to natural vegetative propagation by rhizomes. Since 1997, introductory work has been carried out with them in the botanical garden including phenological observations, the study of the growth and development as well as the chemical composition of the aboveground biomass.

The measurement of productivity was carried out at the beginning of September 2021. The weighing of the aboveground parts of the plants was carried out on a Foo- datlas BT-40C electronic balance (error $0.8 \%$ ). The wet

weight of an individual plant (or shoot) was determined in 5-6 replicates and the dry weight after drying at room temperature in a closed room. Since the plant $P$. weyrichii consists of several stems and it is difficult to accurately establish the belonging of an individual shoot to a bush due to intertwined rhizomes, we measured the mass of an individual stem (shoot) in our studies. The aboveground wet weight was also measured in triplicate from plots with an area of $1-3 \mathrm{~m}^{2}$ and recalculated to the airdry weight.

The data were statistically processed using Excel and Statistica 13 software.

\section{Results}

The growing season of 2021 was characterized by early, extremely warm and dry spring, low rainfall in the first half of summer, and a large number of clear days throughout the season. Temperature records were updated in May and June. The maximum temperatures were 34.7 and $36.0^{\circ} \mathrm{C}$, respectively, the deviation from the long-term average values was 6.3 and $2.4{ }^{\circ} \mathrm{C}$ upward. The average temperature in the summer months was $19.6^{\circ} \mathrm{C}$, which is $2.3{ }^{\circ} \mathrm{C}$ higher than the climatic norm. At the time of harvesting the green mass, the HTC was 0.95 , which characterizes the growing season as hot and sometimes dry.

Table 1 shows the results of measuring the aboveground mass of individual plants of A. caudatus, A. cruentus, E. sphaerocephalus and individual shoots of the $P$. weyrichii.

The values of wet and dry mass of the aboveground part of the studied crops measured at the end of the growing season in 2021 in terms of area are presented in Table 2.

\section{Discussion and Conclusion}

In our studies, $P$. weyrichii proved to be the most productive of agricultural crops. $P$. weyrichii is a perennial shade-tolerant forage plant from the Polygonaceae family, it is a large herbaceous bush-shaped plant with large leaves. The aboveground green mass contains a large amount of protein and ascorbic acid and is used in agriculture for silage, haylage and vitamin feed. In terms of the biochemical composition and nutritional value of the aboveground mass, $P$. weyrichii is not inferior to many traditional agricultural crops. The natural range of $\mathrm{Po}$ lygonum weyrichii are Sakhalin, the Kuril Islands and Japan.

The root system of $P$. weyrichii consists of a welldeveloped main root and adventitious roots, developing from the second year of life. The roots contain many tannins. The stem is straight, slightly curved at the nodes, weakly branched, hollow, grooved. The height of the bush reaches $250 \mathrm{~cm} \mathrm{[3].} \mathrm{The} \mathrm{leaves} \mathrm{are} \mathrm{broadly} \mathrm{ovate,}$ pubescent below. The average leaf length is $30 \mathrm{~cm}$, and the width is $15 \mathrm{~cm}$. The inflorescence is a loose, branched panicle. $P$. weyrichii is a cross-pollinated dioecious plant.

$P$. weyrichii belongs to cold-hardy and winter-hardy plants. Rhizomes are able to withstand frosts down to $-35^{\circ} \mathrm{C}$. Leaves can be partially damaged by late spring and early autumn frosts. It is a moisture-loving but at 
|l the same time drought-resistant plant. Seedlings and young plants in the first year of life are most sensitive to a lack of moisture. Sensitivity to lack of moisture decreases with age. $P$. weyrichii grows slowly in the first year, but then it is distinguished by rapid growth, high yield, ecological plasticity and undemanding cultivation conditions, it grows on various soils.

In the collections of the Botanical Garden of UrFU, P. weyrichii has been cultivated since the 1970s. In our conditions, the beginning of the growth of the knotweed shoots falls on the second decade of May. The plants of knotweed flowering in late July - early August. The end of the growing season of $P$. weyrichii, as a rule, is forced, after the autumn frosts. Seeds rarely ripen, but self-seeding occurs. Insufficiency of seed reproduction is compensated by vegetative propagation by rhizomes: $P$. weyrichii can grow in one place for more than forty years, primarily due to the longevity of rhizomes.

The aboveground mass of $P$. weyrichii cultivated in the botanical garden of Ural Federal University is characterized by a relatively high content of crude protein $(15.66 \pm 2.58 \%$ on dry weight) and protein $(12.13 \pm$ $3.76 \%$ ). Protein nitrogen accounts for $77 \%$ of the total nitrogen. The content of soluble carbohydrates is $4.58 \pm$ $1.49 \%$, fiber $-27.00 \pm 4.89 \%$, ash content $-8.51 \pm$ $1.44 \%$. Macronutrients accumulate in small amounts: calcium $-0.63 \pm 0.07 \%$, phosphorus $-0.32 \pm 0.06 \%$, potassium $-2.81 \pm 0.54 \%$. With age, $P$. weyrichii content of crude protein and protein decreases, while the content of fiber and soluble carbohydrates increases. In terms of the content of nutrients, it is comparable or even superior to the traditional fodder crop of corn grown in the same conditions of the botanical garden.

Introduced in the botanical garden of $\mathrm{UrFU}, P$. weyrichii is distinguished by high productivity and undemanding to soil conditions. According to the results of long-term observations under the conditions under study, $P$. weyrichii reaches an average height of $208.0 \pm$ $8.79 \mathrm{~cm}$. In specimens of Weyrich's knotweed, on average, about 40 generative shoots with a large number of leaves are formed. The assimilating leaf surface reaches $41.6 \mathrm{~m}^{2}$ per $1 \mathrm{~m}^{2}$ of soil surface or up to $5.6 \mathrm{~m}^{2}$ per in-

dividual. The average number of internodes is 21 , the length of leaves on a generative shoot varies from 10 to $24 \mathrm{~cm}$. In this case, the leaves account for $29.7 \%$, and the stems $-69.5 \%$ of the total aboveground mass.

The yield of $P$. weyrichii is determined primarily by soil moisture. For seed germination, $60-70 \%$ of water is required from the dry seed mass [4], at the same time excessive moisture also negatively affects plant growth. According to the literature [4], [5], the yield of green mass in the first year is about $30 \mathrm{t} / \mathrm{ha}$, and increase to a value of $80 \mathrm{t} / \mathrm{ha}$ and more in subsequent years. In the botanical garden of UrFU, the weight of green mass changed significantly in different years, averaging $284 \pm 51 \mathrm{t} /$ ha per year. In the dry summer of 2021, the yield of $P$. weyrichii without additional irrigation did not exceed $152 \mathrm{t} / \mathrm{ha}$ wet weight or $36.7 \mathrm{t} /$ ha dry weight, which is a good indicator.

Based on the analysis of the yield of $P$. weyrichii and climatic factors, negative correlations with the sum of positive temperatures $(r=-0.9383 ; p=0.006)$ and a direct correlation with the sum of precipitation $(r=0.8772$; $p=0.022)$, as well as positive correlation with the value of the HTC $(r=0.8270 ; p=0.042)$ at the time of harvesting of the fresh yield.

E. sphaerocephalus is a perennial large herb that grows in the European part of the country and in Western Siberia, as well as in the Caucasus and Central Asia [6]. The root of the glandular globe-thistle is taproot, fleshy. The stem is single, erect, branched at the top, rounded, glandular-pubescent. The leaves are alternate, pinnately dissected, $10-20 \mathrm{~cm}$ long, 4-10 cm wide. Leaves are dark green above, rough with glandular hairs, whitishtomentose below, spinous along the edge. Tubular flowers are collected in large globular inflorescences $3-5 \mathrm{~cm}$ in diameter, gray-blue [7]. E. sphaerocephalus is an excellent honey plant. This plant is of interest as a source of natural biologically active substances and has a high nectar productivity [8], [9]. The advantages of this plant is continuous and constant flowering until the beginning of September as well as the ability to endure a long period of drought. The fruit of E. sphaerocephalus contains alkaloids, mainly echinopsin and fatty oil, which are used in medicine and the pharmaceutical industry.

Table 1

The weight of a plant/shoot of the studied crops in 2021

\begin{tabular}{|l|c|c|c|}
\hline \multicolumn{1}{|c|}{ Crop } & Wet weight, $\boldsymbol{g}$ & Dry weight, $\boldsymbol{g}$ & Water content, \% \\
\hline Amaranthus caudatus L. & $1112.7 \pm 230.2$ & $134 \pm 57.0$ & $74.9 \pm 1.9$ \\
\hline Amaranthus cruentus L. & $534.7 \pm 194.3$ & $76 \pm 46.3$ & $76.8 \pm 1.1$ \\
\hline Echinops sphaerocephalus L. & $332.0 \pm 81.4$ & $74 \pm 17.1$ & $76.6 \pm 11.2$ \\
\hline Polygonum weyrichii F. Schmidt & $344.7 \pm 100.3$ & $64 \pm 25.5$ & $72.9 \pm 1.7$ \\
\hline
\end{tabular}

Table 2

The yield of the studied crops in 2021

\begin{tabular}{|l|c|c|}
\hline \multicolumn{1}{|c|}{ Crop } & Fresh yield, $\boldsymbol{t} / \boldsymbol{h a}$ & Dry yield, t/ha \\
\hline Amaranthus caudatus L. & 57.3 & 10.8 \\
\hline Amaranthus cruentus L. & 44.1 & 10.2 \\
\hline Echinops sphaerocephalus L. & 64.4 & 27.8 \\
\hline Polygonum weyrichii F. Schmidt & 152.4 & 36.7 \\
\hline
\end{tabular}


Echinops sphaerocephalus propagates by seeds, in the first year a rosette of leaves is formed, and in the second year of life it already starts flowering. Regrowth of the stalks of begins in our experimental plots at the end of May and flowering - also at the end of this month and continues throughout the summer. The glandular globethistle fruiting in July - September.

According to the few available literary data, the yield of the fruits of the glandular globe-thistle in culture is $8 \mathrm{c} / \mathrm{ha}$ [7]. The study of biomass yield of E. sphaerocephalus was of great interest for us in order to assess the prospects of its cultivation for sequester carbon dioxide. At the end of the growing season, the average wet weight of a single plant was $332 \pm 81.4 \mathrm{~g}$ in 2021, which is less than the mass of $P$. weyrichii, but at the same time its air-dry weight was higher (Table 1). E. sphaerocephalus accumulates water least of all: the water content is only $55 \%$ in its aboveground mass.

Amaranths are annual herbaceous plants. The root system of $A$. caudatus and A. cruentus is pivotal, highly branched, deeply penetrating into the soil. Amaranth varieties differ in size, shape and color of stem, leaves and inflorescences. The stem of amaranth is usually simple or branched, with many leaves. Plant height is $150-200 \mathrm{~cm}$. Leaves are alternate, whole, with a petiole. The leaves on the plant vary in size from small to large. The flowers are collected in dense spike-paniculate complex hanging or erect inflorescences. Small seeds ripen in inflorescences. One plant can form up to one hundred thousand seeds.

The yield of aboveground green mass in different varieties of amaranth species, some varieties have a high yield of up to $1500-2000 \mathrm{c} /$ ha [9]. The growing season until the seeds are fully ripe is about 100-120 days. Amaranths are demanding for heat and not demanding for moisture [10].

The high productivity of amaranth is due to the fact that a special type of $\mathrm{C}_{4}$ photosynthesis occurs in its leaves [12], which differs from that which occurs in the leaves of plants in our temperate climate. Such plants continue to photosynthesize in hot tropical climates at $35-45^{\circ} \mathrm{C}$. A higher ability to bind carbon by $\mathrm{C}_{4}$ plants (for example, Zea mays and Sorghum) has been repeatedly noted in comparison with traditional agricultural crops [13]. Based on the analysis of enzyme activity, it was shown that the carbon binding capacity of $\mathrm{C}_{4}$ crops is much higher than that of $\mathrm{C}_{3}$ plants due to the higher activity of phosphoenolpyruvate carboxylase (PEP carboxylase). $\mathrm{C}_{4}$ plants also differ in a different anatomical structure of the leaf, which makes it possible to exchange metabolites more efficiently. These and some other features of $\mathrm{C}_{4}$ plants allow them to produce biomass more efficiently, primarily in conditions of a lack of moisture.

We have found earlier an increase in the $\mathrm{C}_{4}$ properties of amaranth grown under drought conditions, which, according to our assumptions, may be associated with an increase in $\mathrm{CO}_{2}$ reassimilation of respiratory origin [14]. The specified features of $\mathrm{C}_{4}$ plants predetermine the increased interest to them in the context of climatic trends in the Middle Urals, including within the framework of the carbon theme.

Phenological observations carried out by us [15] showed that the main limiting factors in the development of annual amaranths in a temperate continental climate are low summer temperatures, excessive moisture, and a short meteorological summer. Amaranth is a drought-resistant plant [14], [16]; hot dry years with a HTC value of less than one are considered optimal for the maturation of amaranth seeds. The growing season of 2021 turned out to be favorable for the growth and development of amaranths. In the conditions of the botanical garden, according to the results of long-term observations, the plants $A$. caudatus reached an average height of $171.8 \pm$ $2.4 \mathrm{~cm}$, and $A$. cruentus $-168.1 \pm 3.1 \mathrm{~cm}$. The total leaf surface of one plant was about $0.2 \mathrm{~m}^{2}$ with an average leaf area $73 \mathrm{~cm}^{2}$.

The productivity of plants of both amaranth species in 2021 was at the level of productivity values in other countries [16] and amounted to 44.1-57.3 t/ha under conditions of non-overgrown plantings. When comparing the aboveground mass of $A$. caudatus and A. cruentus over the years of introduction studies, $A$. cruentus statistically reliably formed a lower biomass (the differences are statistically significant at $p<0.05$ ). Analysis of variance showed that the biomass of amaranths depends not only on species characteristics ( $F=114.77 ; p=0.000001)$, but also on weather conditions in the year of cultivation $(F=43.44 ; p=0.000003)$. At the $p<0.01$ significance level, positive correlations were found with the sum of average daily temperatures above $10{ }^{\circ} \mathrm{C}(r=0.6093$; $p=0.004)$ and the sum of daily maximums $(r=0.6479$; $p=0.002)$ during the growing season of amaranth from emergence to harvesting biomass. Correlations with the sum of the minimum daily temperatures $(r=0.5190$; $p=0.019)$ and the HTC value $(r=-0.4515 ; p=0.046)$ are significant only at the level of confidence $p<0.05$. Correlations with the amount of precipitation during the growing season of amaranths are statistically insignificant. Thus, years with high temperatures are optimal for amaranths; they are less demanding on the moisture regime.

Therefore, a comparison of the yield of different types of large-herb plants allowed us to single out $P$. weyrichii, which is distinguished by high forage productivity. Its introduction into culture can be highly effective, especially in conditions of increased moisture. In some countries, developments are already underway to use $P$. weyrichii for biofuel production [17].

Species diversity is known to have a positive effect on carbon sequestration in agricultural land [18]. In some countries, projects are already being developed for adaptive planting of green spaces including in combination with tree crops in order to carbon more efficiently deposit [19].

Sowing and planting of herbaceous plants in the formation of sustainable ecosystems is the first step to ensure the formation of the humus layer of the soil and the further successful growth of trees and shrubs. Large- 
herb plants that are resistant to biotic and abiotic envi- can be used both in agrophytocenoses and in the reclaronmental factors play the role of pioneer species and contribute to the resilience of ecosystems.

The proposed perennial and annual large-herb crops can be complementary and interchangeable in an increasingly unstable continental climate characterized by alternating wet and dry, cold and warm growing seasons. Such plants gain competitive advantages with climate change and an increase in the concentration of carbon dioxide in the surface layer of the atmosphere [20]. They mation of disturbed areas. To accelerate the binding of atmospheric carbon and its deposition in the aboveground mass, it seems promising to introduce annual plants with the $\mathrm{C}_{4}$ type of photosynthesis into the grass mixture.

Acknowledgements

This work was carried out with financial support from the Ministry of Science and Higher Education of the Russian Federation, the theme of the State Assignment FEUZ-2021-0014.

\section{References}

1. Fedoseeva G. P., Okoneshnikova T. F., Yuzhakov V. I., Halatyan O. V., Radchenko T. A., Bagautdinova R. I., Rymar' V. P., Stefanovich G. S., Skulkin I. M. Model' ispol'zovaniya resursov mirovoy flory dlya formirovaniya nauchno-obrazovatel'nogo prostranstva Ural'skogo regiona [Model of use of resources world flora for formation of scientific-educational space of the Ural region] [e-resource] // Hortus botanicus. 2007. Vol. 4. 23 p. URL: https:// hb.karelia.ru/journal/content_list.php?id=2804 (date of reference: 30.09.2021). (In Russian.)

2. WFO (2021): World Flora Online [e-resource]. URL: http://www.worldfloraonline.org (date of reference: 30.09.2021).

3. Khusnidinov Sh. K., Shumitsky S. N. Morfo-biologicheskaya kharakteristika gortsa Veyrikha [Morpho-biological characteristic of Weyrich's knotweed] // Vestnik IrGSHA. 1998. No. 12. Pp. 37-39. (In Russian.)

4. Efremov V. V. Produktivnost' gortsa Veyrikha v polevom kormoproizvodstve [Productivity of the Weyrich's knotweed in field forage production] // Aktual'nyye voprosy sovershenstvovaniya tekhnologii proizvodstva i pererabotki produktsii sel'skogo khozyaystva. 2018. No. 20. Pp. 30-32. (In Russian).

5. Chupina M. P., Stepanov A. F. Assessment of photosynthetic productivity of new perennial forage crops in foreststeppe conditions of Western Siberia // IOP Conference Series: Earth and Environmental Science. 2021. Vol. 624. DOI: 10.1088/1755-1315/624/1/012121.

6. Zykova E. Y., Shaulo D. N. Nakhodki vo flore Novosibirskoy oblasti [New and rare species in the flora of the Novosibirsk Region] // TURCZANINOWIA. 2021. No. 24 (2). Pp. 19-27. DOI: 10.14258/turczaninowia.23.3.6. (In Russian).

7. Savin A. P., Ryzhenkova A. V. Mordovnik sharogolovyy [Glandular globe-thistle] // Pchelovodstvo. 2013. No. 9. Pp. 18-19. (In Russian.)

8. Skvortsov A. I., Semenov V. G., Sattarov V. N., Baimukanov D. A., Doshanov D. A., Abdullayeva G. A., Faizullayeva L. A. Some results of phenological observations over the main nectariferous-polliniferous plants of the Chuvash Republic // Bulletin the National academy of sciences of the Republic of Kazakhstan. 2020. No. 1 (383). Pp. 121-127. DOI: 10.32014/2020.2518-1467.15.

9. Dokukin Yu. V. Biologicheskiye osobennosti razvitiya mordovnika sharogolovogo [Biological development features of Echinops sphaerocephalus] // Sbornik nauchno-issledovatel'skikh rabot po pchelovodstvu i apiterapii. Rybnoe, 2018. Pp. 115-118. (In Russian.)

10. Chernov I. A., Zemlyanoy B. Ya. Amarant - fabrika belka [Amaranth - protein factory]. Kazan, 1991. 92 p. (In Russian.)

11. Dmitrieva O., Ivanov S. Comparative study of amaranth species (Amaranthus ssp.) in the temperate continental climate of Russian Federation // Acta agriculturae Slovenica, 2020. No. 115/1. Pp. 15-24. DOI: 10.14720/ aas.2020.115.1.1281.

12. Chernov I. A. Amarant - fiziologo-biokhimicheskie osnovy introduktsii [Amaranth - physiological and biochemical foundations of introduction]. Kazan, 1992. 92 p. (In Russian.)

13. Li T., Zhang F., Jiao Y., Zhang M., Chang Y., Matomela N. Study on carbon sequestration capacity of typical crops in Northern China // Journal of Plant Biology. 2019. No. 62 (3). Pp. 195-202. DOI: 10.1016/j.scitotenv.2014.07.047.

14. Valdayskikh V. V., Voronin P. Yu., Artemyeva E. P., Rymar V. P. Amaranth responses to experimental soil drought // AIP Conference Proceedings. 2019. No. 2063. Article number 030023. DOI: 10.1063/1.5087331.

15. Artemyeva E. P., Valdayskikh V. V., Radchenko T. A., Belyaeva P. A. Amaranthus phenology during its introduction in the Middle Urals // AIP Conference Proceedings. 2019. No. 2063. Article number 030002. DOI: 10.1063/1.5087310.

16. Assad R., Reshi Z. A., Jan S., Rashid I. Biology of Amaranths // Botanical Review. 2017. No. 83 (4). Pp. 382436. DOI: 10.1007/s12229-017-9194-1.

17. Kurhak V. H., Tkachenko M. A., Asanishvili N. M., Moisiienko V. V., Holodna A. V., Tkachenko A. M., Slyusar S. M., Ptashnik M. M., Kolomiiets L. P., Tsymbal Ya. S., Oksymets O. L., Kulyk R. M., Panchyshyn V. Z., Stots- 


\section{Agrarian Bulletin of the Urals No. 11 (214), 2021}

ka S. V., Sladkovska T. A. Energy productivity of uncommon herbs for solid fuel manufacturing // Ukrainian Journal of Ecology. 2021. No. 11 (1). Pp. 299-305.

18. Wang C., Tang Y., Li X., Zhang W., Zhao C., Li C. Negative impacts of plant diversity loss on carbon sequestration exacerbate over time in grasslands // Environmental Research Letters. 2020. No. 15 (10). Article number 104055. DOI: 10.1088/1748-9326/abaf88.

19. Wang Y., Chang Q., Li X. Promoting sustainable carbon sequestration of plants in urban greenspace by planting design: A case study in parks of Beijing // Urban Forestry \& Urban Greening. 2021. No. 64. Article number 127291. DOI: 10.1016/j.ufug.2021.127291.

20. Korres N. E., Norsworthy J. K., Tehranchian P., Gitsopoulos T. K., Loka D. A., Oosterhuis D. M., Gealy D. R., Moss S. R., Burgos N. R., Miller M. R., Palhano M. Cultivars to face climate change effects on crops and weeds: a review // Agronomy for Sustainable Development. 2016. No. 36 (1). Article number 12. DOI: 10.1007/s13593-0160350-5.

\section{Authors' information:}

Viktor V. Valdayskikh ${ }^{1}$, candidate of biological sciences, director of the botanical garden, ORCID 0000-0001-9440-8522, AuthorID 142640;+7 912 277-07-22,v_vald@mail.ru

Elena P. Artemyeva ${ }^{1,2}$, candidate of biological sciences, lead engineer of the botanical garden of UrFU, associate professor of natural sciences department of USURT, ORCID 0000-0003-0937-460X, AuthorID 262616; +7912226-19-80,epartemyeva@urfu.ru

Mikhail Yu. Karpukhin ${ }^{3}$, candidate of agricultural sciences, vice rector for scientific work, ORCID 0000-0002-8009-9121, AuthorID 339196; +7 912 253-04-13, mkarpukhin@yandex.ru Roman V. Mikhalishchev ${ }^{1}$, lead engineer of the botanical garden, ORCID 0000-0002-3035-2010, AuthorID 994471; +7 912 693-55-90,botsadurfu@mail.ru

${ }^{1}$ Ural Federal University named after the first President of Russia B. N. Yeltsin, Ekaterinburg, Russia

${ }^{2}$ Ural State University of Railway Transport, Ekaterinburg, Russia

${ }^{3}$ Ural State Agrarian University, Ekaterinburg, Russia 